\title{
Sitting in a Chaucer lecture, naming you
}

\author{
Julie Schroeder
}

La poésie de Julie Schroeder fait converger le sacré et le profane pour diviniser la violence des femmes et l'érotisme. Parsemé de notes tirées d'un cours sur Chaucer pendant lequel la narratrice apprend de quelle manière les saints sont désignés, elle nomme l'objet de son amour à travers un jeu de contrepoints physiques.

Le corps d'Anne est profondément transformé quand elle revient de Los Angeles, à tel point que lorsqu'elle comparaît au tribunal pour un procès, elle a l'air d'une religieuse. Sa mère, qui a été internée parce qu'elle croyait être le Christ, ne peut l'aider avec sa panoplie de médicaments.

Onomastics: the history and origin of naming (divinely inspired); considered to give eminence to Anglo Saxon names. Effect of being with you, of a snug feeling around my ribs, arms clasp shoulders and back. Saint's life made useful to public: divine the saint's name and the application to public life becomes clear So erotic the flavor of your mouth, shared. I would like to swallow you entirely, your mouth and tongue make my jaw squeeze. The way you fit my eye, you me your eye: seeing and not seeing Be careful of how you name your king. fluid loosening desire making me ache, your fingers in, and a rhythm inside and inside outside. you wrap me in a fabric of blindness, contrapuntal Two examples are St. Lucy, whose name means light, and St. Cecelia, who is associated with music. 


\section{untitled}

Anne came back from L.A. with a mouth like a broken jar. Her teeth threaten her lip with their jagged slant. She's plucked her eyebrows to look perpetually skeptical. It's only her nose I recognize. A nose formed by chubby hands under eyes the nowhere blue of Beverly Hills pools.

Said she was fond of black although she didn't wear it in California - jingles ice cubes in a crystal tumbler - only white linen. She'd worn white to court: a long white skirt and vest and a white blouse and carried a black briefcase. Said she looked like a nun. No sign of handcuffs, bruises, antidepressants, Stuart, the transmission tower, photographs, or her gut stitched with fear. Her mother came for the trial. She was in a mental institution because she thought she was Christ. Brought Anne her JESUS SAVES pill box.

When she talks of her mother or time she spent in jail, her eyes look like gelatin not yet set. Her shoulders lose their grip on her posture, and she slips inward, a loose sniggering fall. She's in Ottawa now. 